\title{
The Quest for Gold: Monetary Debates in Nineteenth-century Brazil
}

\author{
A busca pelo ouro: debates monetários no Brasil do século XIX
}

ANDRÉ VILLELA*,**

RESUMO: O artigo examina alguns aspectos das controvérsias monetárias que ocorreram em vários países durante o século XIX. No Brasil, os defensores do padrão ouro e da restrição monetária, conhecidos como metalistas, prevaleceram sobre os papelistas, cujo principal desejo era a expansão monetária e a criação de crédito. Argumentaremos que os tratamentos anteriores dos debates monetários no Brasil do século XIX ignoraram um ponto crucial, a saber, a defesa (ou não) da conversibilidade dos mil-réis. Isso levou a interpretações errôneas da ideologia subjacente à gestão monetária no período.

PALAVRAS-CHAVE: história econômica do brasil; padrão ouro; emissão de moeda; padrão monetário.

ABSTRACT: The paper examines some aspects of the monetary controversies which took place in several countries during the nineteenth century. In Brazil advocates of the gold standard and monetary restraint, known as metalistas, prevailed over papelistas, whose major desire was monetary expansion and credit creation. It will be argued that previous treatments of monetary debates in nineteenth-century Brazil have overlooked a crucial point, namely, the defence (or otherwise) of convertibility of the mil-réis. This has led to erroneous interpretations of the ideology underlying monetary management in the period.

KEYWORDS: Economic history of Brazil; gold standard; money supply; monetary regime. JEL Classification: N16; E51.

\section{INTRODUCTION}

Monetary management was a hotly disputed topic in mid nineteenth-century Brazil. Throughout the debates two broad camps could be identified, metalistas and papelistas. The former, as the name implied, advocated convertibility of note issue

\footnotetext{
* Lecturer, Mestrado em Economia Empresarial na Universidade Candido Mendes, Rio de Janeiro/RJ, Brasil.E-mail: avillela@candidomendes.br.

** Financial support from CNPq is gratefully acknowledged.
} 
on demand, the imposition of strict limits on the money supply and, more generally, adherence to the principles of monetary virtue identified with the gold standard. In short, they favoured what may be termed "hard money" policies. Papelistas, on the other hand, saw no obstacles to the issue of paper money, so long as in proportion to the number of actual transactions undertaken in the economy. The sheer shortage of gold at the domestic level, coupled with pressing demands for credit expansion, they argued, precluded the pursuit of the more orthodox approach preferred by metalistas. Both groups entertained mixed, and often contradictory, views on many issues within the general debate, thus resembling the English monetary controversies of the first half of the nineteenth century. ${ }^{1}$

The article will examine some aspects of the monetary controversies which raged in Brazil in the mid-nineteenth century. In particular, it will look into the finer elements which informed the debate between contemporary advocates of the gold standard and their opponents, who favoured a purely fiduciary note circulation. It will be shown that earlier treatments of the controversies found in the literature fail to grasp important nuances which served to distinguish some of the major participants in those debates.

\section{MONETARY CONTROVERSIES IN HISTORICAL PERSPECTIVE}

When monetary debates were raging in Brazil, in the 1850s and 1860s, the equivalent controversies in Britain had subdued considerably. Two major waves stand out in the history of these debates in Britain. The bullionist controversy, during the Napoleonic Wars, and the Banking school vs. Monetary school polemics from the 1820s onwards. The bullionist controversy concerned different interpretations for the depreciation of sterling after 1808, eleven years into the Restriction Act of 1797, which had suspended gold payments in Britain. In 1810, the Bullion Committee was set up by Parliament to investigate the matter, and opened the way for the fight between bullionists and antibullionists. The former argued in favour of immediate resumption of convertibility and blamed depreciation on monetary factors, that is, an overissue of banknotes. Antibullionists, on the other hand, claimed that depreciation of sterling should be ascribed to "real" (mainly balance of payments) disturbances, caused by war expenditures on the Continent, poor harvests at home, as well as hoarding of specie on account of increasing uncertainty. Accordingly, they argued that resumption of gold pay-

\footnotetext{
${ }^{1}$ On the British monetary controversies, see J. Viner, Studies in the Theory of International Trade (London, George Allen \& Unwin, 1937); F. W. Fetter, Development of British Monetary Orthodoxy, 1797-1875 (Cambridge, Cambridge University Press, 1965); L. White, Free Banking in Britain: theory, experience, and debate, 1800-1845 (Cambridge, Cambridge University Press, 1984); and M. Collins, Money and Banking in the United Kingdom: a history (Cambridge, Cambridge University Press, 1991).
} 
ments should be postponed until "normality" was restored. ${ }^{2}$ for all purposes, the controversy was resolved in 1819 in favour of the bullionists, when a Parliamentary Act determined the resumption of convertibility of Bank of England notes. Having established the overriding principle of convertibility of notes into gold, the debates that ensued would concentrate on the origins of the business cycle and attempts to mitigate it.

Monetary controversies after the Resumption Act involved followers of two broad "schools" of thought, with different views on the business fluctuations that repeatedly hit the British economy. At the heart of the polemics - which pitted the Currency and Banking schools against each other - was the question of whether authorities should follow a set of rules or, to use a modem concept, be allowed discretion in the conduct of monetary policy. ${ }^{3}$ Adherents of the Currency school (prominent among whom were John McCulloch and Loyd Overstone)sought to define the means for achieving a price level which would be the same whether the money supply were one hundred percent metallic or part gold, part paper. ${ }^{4}$ Given that in practice a mixed currency was in place, then it would only operate properly if it were made to behave as gold. Hence the "currency principle", which posited a mechanism whereby 'any influx or efflux of gold (should result) in a corresponding (absolute, not proportional) decrease or increase in the quantity of the currency'. ${ }^{5}$ Banking school advocates (such as John Stuart Mill, Thomas Tooke and John Fullarton) did not share the view that the authorities should be bound by a rule which, in practice, imposed a constraint on monetary policy. ${ }^{6}$ Overissue (and, hence, inflation), they claimed, could not occur so long as convertibility was maintained. Consequently, there should be no "artificial" limit on the operation of the banking system, as reflected in the currency principle. In support of their arguments, adherents of the Banking school adopted three principles which they thought reflected the way in which banks actually operated: the "real bills" and "needs of

\footnotetext{
${ }^{2}$ For an examination of the bullionist controversy, see Fetter, Development, Chapter 2; and W. SantiagoValiente, "Historical Background to the Classical Monetary Theory and the 'Real-Bills' Banking Tradition", History of Political Economy (hereafter, HOPE), Vol. 20, No. 1, Spring 1988, pp. 43-63.

${ }^{3}$ See A. J. Schwartz, "Banking School, Currency School, Free Banking School”, in J. Eatwell et al. (eds.) The New Palgrave Dictionary of Economics (London, Macmillan, 1987), pp. 182-6.

${ }^{4}$ Ibid., p. 183.

${ }^{5}$ Cf. J. Viner, Studies in the Theory of International Trade (New York, Harper Bros., 1937), p. 221.

${ }^{6}$ It has been argued that in positioning itself in favour of discretion, i.e., of a measure of unbound authority, the Banking School could be likened to modern-day Keynesians, while Currency school advocates would resemble monetarists, in seeing as the government's main task the setting of limits to the expansion of the money supply. For an elaboration of this point, see C. Kindleberger, "Keynesianism and Monetarism in Eighteenth - and Nineteenth-Century France", HOPE, Vol. 24, No. 4, Winter 1980, pp. 499-523.
} 
trade" doctrines and the law of reflux. ${ }^{7}$ The real bills (or commercial Joan) theory of banking asserted that restricting bank loans to productive, self-liquidating purposes, ensured against their issuing too much money. The law of reflux, advanced by Tooke and Fullarton, modified the real bills doctrine slightly. According to them, overissue would be possible only in the short run. After that, notes would return to the issuer for repayment of loans, thus acting as a practical check on banks' discount policy. Finally, the needs of trade doctrine established that note circulation should be demanddriven, that is, expanded when business prospered and restricted in the downturn.

In other words, it consisted of a pro-cyclical theory of monetary policy.

With regard to each group's views on the business cycle, both Banking and Currency school theorists generally considered them to originate in non-monetary factors. for them, "speculation" - broadly understood as the ebb and flow of optimism in the economy - was its root cause. Yet, the origin of the waves of optimism themselves was a moot point for both schools. Explanations differed, nevertheless, as to the transmission mechanism in operation. for the Currency school, banks - which responded to the ups and downs of the economy by expanding and contracting their issues - ensured the monetary spread of the cycle, although they were not behind the "original sin". The currency principle, therefore, did not insure against the occurrence of trade cycles but, rather, sought to prevent their amplification. ${ }^{8}$ for the Banking school, nonmonetary factors lay behind both the origin and the spread of business cycles. The reason being that banks passively reacted to greater or lesser demand for credit, as the waves of optimism and pessimism alternated. The following table summarises the main points in the Currency school vs. Banking school controversy.

In spite of the considerable differences of opinion on the many issues outlined above, there was a crucial common thread to both schools of monetary thought. It was the presupposition of convertibility of notes. In other words, their theoretical analyses implied an unequivocal endorsement of the gold standard in practice. Convertibility of notes into specie on demand, and the fixed exchange-rate regime that it implied, was the orthodoxy of the time, against which only a handful of people dared to stand out.

\footnotetext{
${ }^{7}$ For a detailed discussion of these tenets of the Banking school, see D. Glasner, "On Some Classical Monetary Controversies", HOPE, Vol. 21, No. 2, Summer 1989, pp. 201-29; and idem, "The Real Bills Doctrine in the Light of the Law of Reflux", HOPE, Vol. 24, No. 4, Winter 1992, pp. 867-94.

${ }^{8}$ Schwartz, "Banking School”, p. 185.
} 
Figure 1

Schema of the Currency School vs. Banking School Controversy

\begin{tabular}{|c|c|c|}
\hline Issue & Currency School & Banking School \\
\hline $\begin{array}{l}\text { When is money stock self- } \\
\text { regulating? }\end{array}$ & $\begin{array}{l}\text { Only under an imposed rule (the } \\
\text { currency principle) }\end{array}$ & Already \\
\hline Who can overissue? & $\begin{array}{l}\text { Single country banks; country } \\
\text { bans in concert especially likely; } \\
\text { Bank of England }\end{array}$ & No bank \\
\hline Real bills doctrine & Anti & Pro \\
\hline Law of reflux & Muddled, perverse, too slow & $\begin{array}{l}\text { Instantaneous, via loan re- } \\
\text { payments }\end{array}$ \\
\hline Needs of trade doctrine & $\begin{array}{l}\text { Is bad: applies only to country } \\
\text { banks, not to the Bank of England }\end{array}$ & $\begin{array}{l}\text { Is good; applies to both } \\
\text { country banks and the Bank } \\
\text { of England }\end{array}$ \\
\hline \multicolumn{3}{|l|}{ Trade Cycle: } \\
\hline Origin & Nonmonetary & Nonmonetary \\
\hline Transmission & Monetary & Nonmonetary \\
\hline System favoured & Rule-bound authority & $\begin{array}{l}\text { Unbound authority (discre- } \\
\text { tion) }\end{array}$ \\
\hline
\end{tabular}

Source: Adapted from Table 4.1, in L. Whilte, Free Banking in Britain (Cambridge: Cambridge University Press, 1984), p.135.

Gold was thought of as an ideal monetary standard, domestically and internationally, because of its unique qualities both as a store of value and a medium of exchange. Contemporaries were keen to contrast the (alleged) price stability that the gold standard afforded with the "evils" usually ascribed to inconvertible fiduciary money. ${ }^{9}$ The well-functioning of the system would be ensured by means of the operation of the so-called price-specie-flow mechanism, originally proposed by Hume, in 1752. In this model, arbitrage in one commodity (gold) between nations served to maintain balance of payments equilibrium. Essentially, a country running a trade (or balance of payments) deficit lost gold. Domestically, the price of gold went up relative to those of other commodities. As a result, this country gained competitiveness, and increased its exports above its imports. Gold would flow back into the country and the balance of trade was restored. ${ }^{10}$

\footnotetext{
${ }^{9}$ See M. Bordo, "The Gold Standard: the traditional approach”, in M. Bordo and A. Schwartz (eds.) A Retrospective of the Classical Gold Standard, 1821-1931 (Chicago and London, University of Chicago Press, 1984), p. 23.

${ }^{10}$ Looked at from a different angle, after the initial gold loss, the country would suffer a currency and credit crunch, leading to price deflation, increased competitiveness and greater exports. This mechanism would be reinforced by changes in income, so that monetary contraction, by lowering domestic economic activity, brought about lower imports and an improvement in the country's balance of payments.
} 
The sheer simplicity of Hume's model, in spite of its many underlying assumptions, made it attractive as an explanation for the supposed superiority of the gold standard vis-à-vis a fiduciary note circulation. ${ }^{11}$ When joining the gold standard, countries ensured a stable exchange rate and a balance of payments identically equal to zero. But, in the process, automatically relinquished control over their monetary policy. This was precisely why adherence to the gold standard was not unequivocally endorsed by all participants in the monetary controversies of the time. In effect, the ability to influence the money supply lay at the root of two of the major areas of conflict in the financial debates of the nineteenth century: who could issue what (issuing rights) and with what type of backing (convertibility). The next section will examine the latter point.

\section{MONETARY DEBATES IN BRAZIL}

As already noted, one of the main reasons why countries sought to adhere to the gold standard system was the exchange-rate stability it provided. This stability precluded the shifts in income and wealth that accompanied currency fluctuations, and which lay at the root of the political economy of monetary management. In practical terms, stability would be a direct result of the official commitment to the convertibility of domestic currency at a fixed weight of gold.

The importance of the exchange rate in an open economy like Brazil's in the second half of the nineteenth century cannot be exaggerated. This price had a bearing, to name only a few, on the amount of government revenue (which was highly dependent on import taxes) and foreign commitments. Other things equal, an appreciated rate of exchange meant higher imports and customs revenues. Moreover, it minimised the value in mil-réis terms of the expenses of the imperial government in foreign currency. The exchange also had an influence on the price of urban wage goods (many of which were imported), the profitability of the export sector and, more generally, the state of confidence in the economy as a whole. ${ }^{12}$ Finally, exporters of commodities (fazendeiros) tended to favour a slipping exchange, which, $c e-$ teris paribus, increased the domestic value of their sales. Indeed, with most of their costs defrayed in mil-réis, a low rate of exchange meant a net transfer of resources from society as a whole to the export sector.

The first concrete step towards establishing a gold-backed currency in Brazil

\footnotetext{
${ }^{11}$ For a discussion, see W. M. Scammel, "The Working of the Gold Standard”, in B. Eichengreen (ed.) The Gold Standard in Theory and Practice (New York, Methuen, 1985).

12 At the time, the degree of protection afforded to import-substituting industries by a depreciated milréis, as well as its influence on the imports of capital goods (and, hence, domestic investment) were not significant.
} 
was taken on 11 September 1846, with Law $401 . .^{13}$ This very succinct piece of legislation comprised two main articles.

Art. 1: from 1 January 1847 onwards, or earlier, if possible, the public stations (tax offices) shall accept 22-carat gold coins at the ratio of four mil-réis to the oitava $(. . .)^{14}$

Art. 2: The Government is authorised to retire from circulation the amount of paper money deemed necessary to raise and keep it at the value provided in the preceding Article; for this purpose, it will be allowed to undertake the necessary credit operations.

The intentions of the government in advancing the 1846 Law were clear: the country should strive towards a convertible currency at the new $27 \mathrm{~d}$ parity ${ }^{15}$ Still, it must be emphasized that this exchange rate was more of a "notional" nature, given that monetary circulation at the time consisted mainly of Treasury notes, but also bank-issued vales (short-term promissory notes), both of which were inconvertible. In practice, at that stage the country would still be under a regime of flexible exchange rates, given that no part of its note circulation was backed by gold, nor was it redeemable into it on demand. Indeed, convertibility would only come about after the creation of the third Bank of Brazil, in 1854. On the occasion, the Bank was entrusted with the issue of notes backed by gold or Treasury paper. At the same time, it was required to retire from circulation 2,000 contos' worth of government notes, in an effort to ensure in the medium term that monetary circulation in the Empire would consist solely of convertible paper.

Even though the spirit of the 1846 legislation would dominate most policy actions in the monetary and banking realm in the $1850-70$ period, the $27 \mathrm{~d} / 1 \$ 000$ gold parity was effectively in force for fewer than six years: between April 1854 and November 1857, briefly between August 1858 and January 1859, and then again between October 1862 and the outbreak of the Souto crisis, in September 1864. These were the periods in which the Bank of Brazil - and, for a while, a few, smaller, banks of issue - ensured convertibility of their notes into gold and, as a result, the exchange rate remained near par. Still, this was a peculiar type of gold standard regime. Unlike a traditional gold standard, or the gold exchange standard, note issues in these periods, as noted, were backed partly in gold, and partly in Treasury notes. Yet, Treasury notes were inconvertible, so that by giving them in return for its notes (as it usually did) the Bank of Brazil was technically converting

\footnotetext{
${ }^{13}$ The project for the 1846 Law had originated in the Senate, at the initiative of Bernardo de Vasconcelos. For a sample of the discussions in Parliament over the 1846 monetary reform, see A. Cavalcanti, O Meio Nacional (Rio de Janeiro, Imprensa Nacional, 1893, 2 vols.), Vol. 2, Chapter 2.

${ }^{14}$ An oitava corresponded to $1 / 8$ of an ounce, or 3.586 grams.

15 This was the third time the legal parity of the mil-réis was changed. Historically, the par rate of exchange had been $67.5 \mathrm{~d}$, altered to $43.4 \mathrm{~d}$ in 1833 .
} 
its own money into paper, not gold. Still, even with this peculiar system in place, exchange rate stability was observed. As it turned out, the simple pledge to redeem its notes into either gold or Treasury notes - in other words, "potential" convertibility - appears to have built credibility into the system, and ensured that the milréis remained around its par value. Indeed, it must be remembered that when a country is effectively under gold, its exchange rate can only vary within the narrow limits of the gold points. Outside this, specie will either flow into or out of its borders, thus redressing balance of payments surpluses or deficits. A look at the behaviour of the exchange rate in the period when Brazil was "potentially" under gold reveals little deviation from the $27 \mathrm{~d} / 1 \$ 000$ par value, when allowing for a cost for insurance and shipping of gold as high as $4 \%$ of its price.

Table 1

Rate of Exchange Under Convertibility of Bank of Brazil Notes: par 27d (in pence per mil-réis)

\begin{tabular}{lcc}
\hline Period & \multicolumn{2}{c}{ Exchange Rate } \\
\cline { 2 - 3 } 10 April 1854 to 11 Nov 1857 & $283 / 4$ & Low \\
24 Aug 1858 to 17 Jan 1859 & 27 & $26 / 4$ \\
23 Oct 1862 to 14 Sept 1864 & $275 / 8$ & 26 \\
\hline
\end{tabular}

Source:Daily quotations at the Rio Bolsa, in Junta dos Corretores de Fundos Públicos da Cidade do Rio de Janeiro, "Livro Official de Cotações de Títulos e Valores", various vols.

Apart from the intervals displayed in Table 1, Brazil was under a fiduciary system and, therefore, could not possibly benefit from the same degree of exchangerate stability as when it was under this peculiar type of gold standard regime. Still, monetary "virtue" was hailed as paramount and, accordingly, most policymakers and contemporary commentators favoured convertibility.

In the Brazilian historiography, individuals who proclaimed the virtues associated with hard money have been labelled metalistas, whose ideas would be broadly akin to those of the Currency school in England. ${ }^{16}$ The Visconde de Itaboraí and Torres Homem were the main exponents of financial orthodoxy in the mid-nineteenth century. Papelistas, on the other hand, would be the Brazilian equivalent of the Banking school. ${ }^{17}$ Bernardo de Souza Franco was the undisputed leader of this current. ${ }^{18}$ The intellectual legitimacy for either camp was afforded by constant

\footnotetext{
${ }^{16}$ See F. M. de Saes, Crédito e Bancos no Desenvolvimento da Economia Paulista, 1850-1930 (São Paulo, IPE/USP, 1986), p. 26.

${ }^{17}$ Ibid. See also A. M. R. de Andrade, “1864: conflito entre metalistas e pluralistas” (unpublished M.Sc. dissertation, Universidade Federal do Rio de Janeiro, 1987).

${ }^{18}$ Major politicians identified with the metalistas were Angelo Muniz da Silva Ferraz (President of the Council of Ministers and Minister of Finance from August 1859 to March 1861), Paulino José Soares
} 
reference in the debates to foreign authors. Gilbart, an English author identified with the Free Banking school, was a favourite, having had one of his works translated into Portuguese..$^{19}$ Hume, Smith, Ricardo, Mill, and other key participants in the English monetary controversies, were cited with varying degrees of familiarity. Additionally, some of the major tenets of the Currency school vs. Banking school controversy - such as the currency principle and the needs of trade doctrine - were repeated as undisputed truths.

Apart from the guarantee arising from the prompt redemption of banknotes, the total sum of paper-money in each country must vary in amount and value in a similar manner as it would vary (...) if replaced by a metallic currency. ${ }^{20}$

(It is) an undeniable principle that the circulation of banknotes, redeemable in gold on demand, is always determined by the needs of the market, or of the circulation, and cannot go beyond (those needs). ${ }^{21}$

A cursory look at the introductory section to most of the reports of the Minister of finance in the 1850-70 period provides as good a summary as any of the dominant orthodox credo on financial matters. A typical claim by a metalista would read as follows:

(...) the essential condition which industry everywhere needs in order to grow and prosper is the stability of the value of the instrument used in the circulation of its products. This condition is met by a metallic currency, which, on account of the precious material from which it is made, is the universal equivalent, the uniform and almost invariable unit of all other values, the basic product to which they are reduced, as into a common denominator. Bank paper - a mere promise to pay - cannot replace it in circulation unless under the condition of it being converted into this real object (...).22

\footnotetext{
de Sousa (Visconde de Uruguai) and José Maria da Silva Paranhos (Visconde de Rio Branco). With Souza Franco's ideas sided Irineu Evangelista de Souza (Barão de Mauá), João Lustosa da Cunha Paranaguá and José Antonio Saraiva, to name the most important. See A. C. R. de Andrada, Bancos de Emissão no Brasil (Rio de Janeiro, Ed. Leite Ribeiro, 1923), p. 112.

${ }^{19}$ J. W Gilbart, A Practical Treatise on Banking (London, Brown, Green and Longmans, 1856, 2 vols., $1^{\text {st }}$ edn. 1827), translatedby L. J. de Oliveira e Castro as Tractado Practico de Bancos (Rio de Janeiro, Garnier, 1859, 3 vols.). I am indebted to Carlos Gabriel Guimarães for drawing my attention to the Brazilian edition of the Gilbart book.

${ }^{20}$ Cf. Relatório da Commissão de Inquérito Nomeada por Aviso do Ministério da Fazenda, de 10 de Outubro de 1859 (undated), p. 53.

${ }^{21}$ Cf. Relatório da Commissão Encarregada pelo Governo Imperial por Aviso do Primeiro de Outubro e 28 de Dezembro de 1864, de Proceder a um Inquérito Sobre as Causas Principais e Accidentaes da Crise do Mez de Setembro de 1864 (Rio de Janeiro, Typ. Nacional, 1865), p. 76.

${ }^{22}$ Minister Torres Homem, in Proposta e Relatario Apresentados á Assembléa-Geral Legislativa Pelo Ministro e Secretario d' Estado dos Negócios da Fazenda - 1858, p. 2.
} 
Souza Franco's views on the subject of convertibility, as expounded in his 1848 book, were:

Of itself (...) metallic circulation, or (circulation) under a metallic base and bank paper redeemable on demand, is preferable to non-redeemable Treasury notes (...). And the main reason for this is that precious metals are for general use and, being independent of the credit of public or private establishments, the circulating medium is not subject to repeated oscillations in value, which is totally lost as a result of fortuitous and unforeseen events. The same can be said of the notes of well-organised banks of issue, for they will always retain in reserve metal and bonds representing good debt in order to ensure convertibility (of their notes) into metal on request. ${ }^{23}$

Quite clearly, Souza Franco, the champion of the papelistas, was not so distant from his fierce opponent Torres Homem as far as support of a gold-backed currency was concerned. In this respect, both men were in tune with the "sound" monetary principles of their time. Like Currency school and Banking school advocates, both papelistas and metalistas maintained that adherence to the gold standard was paramount. This point is most important. It suggests the need for caution when interpreting the term papelista, which might convey the false impression of a supporter of a purely paper circulation, in clear opposition to the gold standard dogma of the day. The broad metalista vs. papelista dichotomy found in the literature usually fails to grasp this crucial point in the debate, namely, the defence (or opposition to) the gold standard. ${ }^{24}$ There is no doubt, for instance, that Souza Franco was in favour of exercising strict government supervision of the six new banks of issue which he authorised as Minister of Finance in 1857 and 1858. Proof of this, on the occasion he imposed limits to their issue of (partly) gold-backed notes.

According to some, the strength of the gold standard doctrine at the time was actually part of a broader defence of the monopoly of note issue by the Bank of Brazil, which was broken when Souza Franco extended this privilege to other banks. ${ }^{25}$ For this reason, Andrade uses the term "pluralist" in her work, instead of papelista, while arguing that it would be equally valid to refer to metalista-monopolists. ${ }^{26}$ As already suggested, this taxonomy can be misleading. Indeed, a metalista should, in theory, be in favour of metal (gold). Yet, as noted, Souza Franco, a papelista and pluralist, supported a gold-backed circulation as well. In this sense, his position was in fact similar to the Banking school's, which, like the Currency school, never questioned the idea of convertibility itself. This point is worth em-

\footnotetext{
${ }^{23}$ B. de S. Franco, Os Bancos do Brasil (Brasília, Ed. da Universidade de Brasília, 1984, 1st edn. 1848), p. 87.

${ }^{24}$ See, for example, Saes, Crédito, Part I; and Andrade, “1864”.

${ }^{25}$ Ibid.

${ }^{26}$ Ibid., p. 168.
} 
phasizing, for the term papelista has often been used in a derogatory sense, as depicting irresponsible inflationists. Souza Franco's influential book, written in 1848, contains ample evidence of how mindful he was of the need to combine a banking system which would simultaneously meet two objectives: to foster the economic development of Brazil while maintaining the stability of the currency. Moreover, this would be attained, he argued, through convertible notes, not by means of a fiduciary circulation.

Contemporary references to the two schools of thought are very scarce, the terms papelista and metalista apparently having been disseminated by twentiethcentury writers. ${ }^{27}$ Yet, the research has unearthed a rare, and comprehensive, definition of papelistas, given in the Senate by Itaboraí, when asked by Souza Franco.

They are those who proclaim that bank paper is capital, that it is desirable to create many banks, so as to have a larger circulating medium, for the greater the sum, the greater the number of transactions, and the greater the public wealth. They are those who create banks without imposing on them the indispensable conditions that will guarantee the redemption of their notes in gold (...), those who believe that banks, when under extraordinary circumstances, in which the gold reserve tends to fall and the portfolio to increase, should expand their operations (...). Those are the papelistas. ${ }^{28}$

In Itaboraí's definition, then, papelistas were advocates of plurality of issue, who paid little attention to prudential rules, and advocated counter-cyclical monetary policies in the event of panics. Yet, like metalistas, they were supporters of goldbacked issues. Now, who were the "true" papelistas, in the sense of advocates of a purely fiduciary circulation? One needs to look no further than to Irineu Evangelista de Souza, Barão (later Visconde) de Mauá. He was a close friend of Souza Franco's, whose thoughts and policies on money and banking he strongly supported. Nevertheless, Mauá entertained ideas on the subject that were in essence much more radical. Throughout his prolific trajectory as the most important businessman in the Empire, he advocated the virtues of the "spirit of association". In terms of banking legislation, this translated into a much bolder approach to the question of plurality of issue than Souza Franco's. His stance against convertibility of banknotes into gold was heretic at the time, and clearly set him apart from his illustrious papelista friend. The chapter on the "Circulating Medium in Brazil", published in his 1878 autobiography, summarises Mauás view on the question of convertibility:

\footnotetext{
${ }^{27}$ An early example is J. F. Normano, Brazil: a study of economic types (Chapel Hill, NC, The University of North Carolina Press, 1935), p. 190.

${ }^{28}$ Debate held on 2 June 1858, in Annaes do Senado do Império, Tome II, p. 14.
} 
If metallic currency, and banknotes convertible on demand, constitute the engine par excellence of the monetary transactions of most countries, on account of their not being just orders on the capital of the country but (of their) having the advantage of being accepted (...) by the value convened by their mint price (...), it does not follow that these superlative conditions of an excellent circulating medium (...) could not be replaced at again, at a substantial gain even, by temporary, non-convertible paper from banks (...) which may be led by special circumstances (...) to keep in their portfolios not gold, but private and State paper of good credit (...)..$^{29}$

Mauá admitted that issuing banks had committed excesses. 'To the use of bank notes, followed misuse: the mission of the statesmen was to curtail the latter by means of restrictive legislation (... ') ${ }^{30}$ Nevertheless, as a rule, he opposed the straitjacket that a gold-backed circulation would impose on the credit system. Nor was he an irresponsible inflationist either, as the above remarks testify to. His hand is clearly seen in the text of the commission set up by the Bank of Brazil in reaction to the 1860 Law of Impediments (Law 1083). ${ }^{31}$ On that occasion, the commissioners criticised both the currency principle and the real bills doctrine. They argued that there did not exist a "magic" relationship between the amount of currency in circulation and the number of transactions carried out in the economy. Instead, they suggested that the velocity of circulation depended on the state of confidence at a given point in time. ${ }^{32}$ Finally, the report remarked on the adverse effects which the supposedly "natural" adjustment mechanisms of the gold standard had had in places like Great Britain, stressing that they would be even greater if a capital-importing nation like Brazil followed the desideratum of the 1860 Law. $^{33}$

${ }^{29}$ Emphasis added. Cf. B. Mauá, "O Meio Circulante”, in C. Ganns (ed.) Visconde de Mauá: Autobiografia (Exposição aos Credores e ao Público) Seguida de O Meio Circulante no Brasil (Rio de Janeiro, Zélia Valverde, 1942, originally published in 1875), p. 316. For an examination of Mauá's ideas on the gold standard, see S. Fernandes, "Mauá, o Economista do Império: análise de sua crítica científica ao padrãoouro", Revista Brasileira de Economia, Vol. 28, No. 2, April/June 1974, pp. 3-28.

${ }^{30}$ Mauá, “O Meio Circulante”, p. 319. Mauá's defence of inconvertible banknotes had already been made public much earlier, in his testimony to the enquiry into the 1857 commercial crisis. See Commissão de 1859, Annex A, p. 96.

${ }^{31}$ See Banco do Brasil, Parecer Apresentado á Assembléa Geral dos Accionistas do Banco do Brasil pela Commissão Especial Eleita em 2 de Maio de 1861 (Rio de Janeiro, Villeneuve, 1861). Law 1083 was promulgated on 22 August 1860. Essentially, it reaffirmed provisions of the 1850 Commercial Code concerning the operation of corporations and partnerships. As regards banks, it set out a time frame for existing banks of issue to resume convertibility of their notes into gold.

32 lbid., pp. 14-5.

${ }^{33}$ lbid., pp. 16-7. As noted by many authors, the gold standard operated differently in the countries at the centre and those in the periphery of the world economy, the latter being frequently hit by convertibility crises, devaluations and internal dislocations. In effect, borrowing countries were not as capable as "core" ones to control the rate of their capital imports. For the periphery, buoyant economic activity led to merchandise imports picking-up and, eventually, to a trade deficit. In the early stages of the cycle, this 
Mauá was not alone in perceiving the potential damaging effects which the operation of the gold standard could have on Brazil. For Sebastião Ferreira Soares, a contemporary statistician,

\begin{abstract}
Everything that has been said in the chambers and outside about the metallic circulating medium are nice theories, which fail completely in practice, for no State will succeed in retaining gold and silver coins in circulation unless the value of production and exports is greater than imports and consumption (...). Brazil will not achieve a stable circulating medium in gold and silver, as desired, unless its exports exceed its imports, and the most advantageous medium will be the one that we had earlier, with very few changes. ${ }^{34}$
\end{abstract}

These remarks were made at the same time as the government's determination to impose limits on the banks of issue was at its highest, namely, on the eve of the enactment of the 1860 Law of Impediments. ${ }^{35}$ With the Law, banks created by decree in 1857-8 were barred from issuing notes in excess of their average outstanding issues in the previous semester, until they could ensure convertibility into gold. As for the Bank of Brazil, unless it also resumed convertibility, its note issue could

trade deficit would be financed by (foreign) capital inflows which, by their inherent volatility, were bound to return to their countries of origin at news of panics and the subsequent increases in Bank (of England) Rate. Given the lagged response of import demand to credit conditions, this capital flight could result in severe reserve lasses which, under the gold standard, would bring about an equally strong monetary contraction. Depending on the magnitudes involved, that is, the size of the gold drain relative to the domestic monetary base, the ensuing deflation could be considerable. In short, capital flows tended to be pro-cyclical, that is, they would increase in boom times and as soon as the slump set in (but merchandise imports were still on the rise), they would return to the centres from where they had originated. This would aggravate the "natural" instability which derived from the periphery's frequent reliance on the exports of one or two primary products. See A. G. Ford, The Gold Standard: 1880-1914, Britain and Argentina (Oxford, Clarendon Press, 1962). For a discussion of these issues as applied to Brazil, see Wfritsch, Externa/ Constraints on Economic Policy in Brazil, 1889-1930 (London, Macmillan, 1988). Furtado had made a similar point earlier, when describing the economy of nineteenth-century Brazil and its incapacity to adapt to the rules of the gold standard in the period. See C. Furtado, Formação Econômica do Brasil (São Paulo, Cia. Editora Nacional, 1970, 10 th edn.), Chapter 27.

${ }^{34}$ Cf. S. f. Soares, Notas Estatísticas Sobre a Produção Agrícola e a Carestia dos Gêneros Alimentícios no Império do Brasil (Rio de Janeiro, IPEA/INPES, 1977, 1st edn. 1860), p. 312. Soares' reference to "exports in excess of imports" (a trade surplus), as he himself elaborates in his book, would refer in modem parlance to the need for a balance of payments surplus if gold and silver coins were to be retained domestically.

${ }^{35}$ Mauás and Soares' advocacy of paper currency, as already noted, was highly atypical in a world convinced of the superiority of the gold standard. In this respect, they were close to the Birmingham economists of the nineteenth century, who favoured inconvertible paper money as a means to enhance employment in times of distress in their city. In a debate in the Senate, Jequitinhonha stated that Souza Franco's opinions in favour of plurality of issue were akin to those of the Birmingham school, 'whose theories had been proven false'. See Annaes do Senado do Império, Tome 1, 1858, p. 244. On the opposition of the Birmingham economists to deflation and the gold standard, see Fetter, Development, pp. 177-80. 
not exceed the quarterly average of its outstanding issues counting from the day it began operating, until March 1860. Three of the seven banks of issue (the Bank of Brazil, Banco de Pernambuco, and Banco do Maranhão) were immediately forced to contract their issues as a result of the new legislation. In 1861, the Banco do Rio Grande do Sul relinquished its issuing rights, and was joined in the following year by the Rural \& Hipotecário. As to the Comercial \& Agrícola, it merged with the Bank of Brazil in September 1862, transferring to the latter its issuing rights. One month later, the Bank resumed convertibility of its notes, after almost four years in which they were redeemed in Treasury paper.

This new phase of convertibility would only last until the outbreak of the Souto Crisis, in September 1864, when the Bank sought (and received) government approval to suspend the obligation to redeem notes in gold. Conceived as an exceptional measure to protect its metallic fund, this new episode in suspension of convertibility of the notes of the Bank of Brazil would prove to be the last. Two years later, in September 1866, financial needs arising from the Paraguayan War led the government to announce a radical review of its agreement with the Bank. As a result of this innovation, the Bank lost its issuing powers, which were transferred back to the Treasury. The government would once again be in charge of the printing press. Massive issues of fiat money followed and return to the gold standard would have to wait until bold financial reforms were introduced in $1888 .{ }^{36} \mathrm{After}$ more than two decades of monetary struggle, financial conservatives had obtained a half-victory. If, on the one hand, they were unable to impose a fully gold-backed currency - the ultimate goal of every metalista - they succeeded in restoring centralisation of note issue. This would prove crucial for the war effort.

\section{CONCLUDING REMARKS}

To sum up, it was seen that monetary debates were commonplace in many countries in the nineteenth century. In England, once the bullionist controversy was over; Currency and Banking school supporters fought over the type of rules which should be imposed on the operation of banks issuing gold-backed notes. Meanwhile, monetary controversies in Brazil were still at an earlier stage. Adherence to the gold standard, while advocated by the majority, was not unequivocally endorsed.

Throughout most of the 1850-70 period Brazil operated a fiduciary system. In practice, convertibility was in force for less than a quarter of the time. Nevertheless, it was shown that most policymakers - even those, like Souza Franco, identified with liberal banking policies - supported adherence to the gold standard, a point ignored in the existing literature. This was then seen as the most effective means to ensure a stable macroeconomic environment. A fixed and, preferably, appreciated

\footnotetext{
${ }^{36}$ For details, see G. H. B. Franco, Reforma Monetária e Instabilidade Financeira Durante a Transição Republicana (Rio de Janeiro, BNDES, 1986), Chapter 3.
} 
rate of exchange, would avoid income and wealth shifts, while it provided the sound money credentials that attracted foreign praise and capital. It was shown that despite Brazil's failure to adopt a gold-backed circulation during most of the period, monetary virtue was pursued almost relentlessly. Contemporaries, as noted by an observer, seemed indeed to have been for the most part "blind admirers of gold". ${ }^{37}$ And this blindness was shared by both metalistas and papelistas.

37 'Every one of our Ministers of Finance (...) advocates of monopoly or plurality of banks, from Torres Homem to Souza Franco, all of them are blind admirers of gold'. Cf. H. A. Milet, O Meio Circulante e a Questão Bancária (Recife, Typ. Do Jornal do Recife, 1875, 2 ${ }^{\text {nd }}$ edn., 1st edn. 1860), p. 25. 